\title{
The effect of exotic grass Urochloa decumbens (Stapf) R.D.Webster (Poaceae) in the reduction of species richness and change of floristic composition of natural regeneration in the Floresta Nacional de Carajás, Brazil
}

\author{
LEANDRO V. FERREIRA ${ }^{1}$, PIA PAROLIN ${ }^{2,3}$, DARLEY C.L. MATOS ${ }^{1}$, DENISE \\ A. CUNHA ${ }^{1}$, PRISCILLA P. CHAVES ${ }^{1}$ and SELVINO O. NECKEL ${ }^{4}$
}

\begin{abstract}
${ }^{1}$ Museu Paraense Emílio Goeldi, Coordenação de Botânica, Av. Perimetral, 1901, Terra Firme, 66077530 Belém, PA, Brasil ${ }^{2}$ INRA, Univ. Nice Sophia Antipolis, CNRS, UMR 1355-7254 Institut Sophia Agrobiotech, 06900 Sophia Antipolis, France ${ }^{3}$ Dept. Biodiversity, Evolution and Ecology of Plants, Biocentre Klein Flottbek, University of Hamburg, Ohnhorststrasse 18, D-22609 Hamburg

${ }^{4}$ Universidade Federal de Santa Caratina, Laboratório de Ecologia de Anfíbios e Répteis, Campus Universitário, s/n, Sala 219B, Bloco B, $2^{\circ}$ andar, Córrego Grande, 88040-900 Florianópolis, SC, Brasil
\end{abstract}

Manuscript received on February 18, 2015; accepted for publication on May 28, 2015

\begin{abstract}
The introduction of exotic species is considered as one of the major causes of biodiversity loss. The National Forest of Carajás is one of the largest mineral provinces in the world. Mining activities caused changes of the natural habitats, leaving degraded areas after the mineral exploitation. One of the mining areas within FLONA Carajás was used for the extraction of gold. In the process of exploitation, a huge depression was formed by the removal of soil which was mounded up nearby. To prevent soil erosion of these mounds, an exotic grass, Urochloa decumbens (Stapf) R.D.Webster (Poaceae) was planted. The objective of this study was to compare the impact of this non-native grass on species richness and species composition of the natural regeneration in the degraded areas. Four areas were compared, two with and two without presence of $U$. decumbens. In each area, twenty four $1 \mathrm{~m}^{2} /$ plots were established. Species richness of the regeneration areas and population sizes were significantly lower in the plots where the exotic grass was present. Our study shows that $U$. decumbens had a negative effect on species richness and population density, and its presence changed the species composition and distribution of life forms of the natural regeneration.
\end{abstract}

Key words: exotic species, degraded areas, floristic, mining.

\section{INTRODUCTION}

Mining activities imply some of the most serious forms of environmental degradation, because the extraction of ores causes the removal of vegetation and soil organic layers, leaving the area degraded

Correspondence to: Leandro V. Ferreira

E-mail: lvferreira@museu-goeldi.br
(Salomão et al. 2007). The natural regeneration common to natural ecosystems does not occur in such heavily degraded areas (Carpanezzi et al. 1990). The main limiting factors for the establishment of plant species after the mining process are soil compaction and the scarcity of nutrients and organic matter in the remaining 
substrate, fundamental for plant growth in the recovery process (Corrêa and Leite 1998).

Depending on the degree of environmental degradation, after the human impact, different processes and techniques of recovery can be chosen and different plant species may be employed for the restoration area (Salomão et al. 2007). The main methods used for the recovery of degraded areas by mining include planting of grasses (Ray and Brown 1995), soil enrichment and/or cultivation of native or exotic tree species (Tilstone et al. 1998).

It is recommended to use species which are native to the region, respecting the successional stages (Kageyama and Gandara 2004). The recovery should begin with the planting of native pioneers, and finish with native climax species, with the goal of re-establishing a vegetation pattern as close as possible to the original matrix.

In Amazonia, restoration of areas degraded by mining has taken place since the 1980s (Salomão et al. 2007). Initially, the emphasis for recovery lay on the control of erosion or on aesthetic aspects. After the 1980s the concerns were directed also towards aspects of the recovery of biodiversity of altered areas (Salomão et al. 2007).

The region of Carajás in the State of Pará, northern Brazil, including the National Forest of Carajás (FLONA de Carajás), is currently one of the leading mineral provinces in the Brazilian Amazon. Most of the world's iron ore and other minerals such as gold, cassiterite, manganese, copper and nickel, are extracted in this nature conservation unit.

For soil recovery and regeneration, the exotic grass Urochloa decumbens (Stapf) R.D.Webster, originating from South Africa was planted in large areas. The advantages to employ this species were seen in fast growth and high resistance to adverse growing conditions as those found in heavily degraded areas (Bianco et al. 2000). The alien species was seen as one of the few able to tolerate toxicity and at the same time minimize the process of erosion caused by the intense rains that occur in the Amazon.

However, this alien species, once introduced, has become invasive and reproduces and disperses beyond the point of introduction. Changes of the local vegetation and impacts on other native organisms present in the original environment are a consequence causing important damages at environmental, social and economic levels (Begon et al. 2007).

Especially natural succession of plant species and the re-establishment of a diverse flora in areas of recovery are inhibited by the presence of this invasive alien species. The International Union for Conservation of Nature (IUCN) and the Brazilian Government identify invasive species as the third largest threat to biodiversity, after habitat loss and direct effects on native species (Sestren-Bastos 2007, Alho et al. 2011).

Studies on the impact of invasive plants demonstrate that they tend to change nutrient cycles, primary productivity, trophic chains, as well as vegetation structure, and species dominance and distribution (Ziller 2001)

$U$. decumbens is an exotic invasive grass that combines a set of features which allow the plant to compete with native species and dominate in the invaded areas. High growth rates, a highly efficient photosynthetic performance, the capacity of resprouting and high regeneration rates, the effective use of nutrients, and also a high tolerance to defoliation and herbivory are among the characteristics which make this species extremely successful in colonizing degraded open areas (Kolar and Lodge 2001). The high efficiency in establishment is due to the fast reproductive cycle and an intense production of seeds which possess high viability and form dense seed banks with high capacity for germination (Kolar and Lodge 2001).

Grasses in general are among the most efficient invasive organisms (Strayer 2012) with a great ability to colonize open areas and to outcompete local species. The impact of $U$. decumbens in 
particular has been documented in some studies which show that this herb is extremely aggressive in its growth and propagation and quickly covers large areas at the expense of the local species composition and diversity (Matos and Pivello 2009, Alho et al. 2011).

In the present study we focus on the exotic grass $U$. decumbens which was deliberately introduced into the degraded sites of the National Forest of Carajás two decades ago. The objective of the study was to determine the impact of this species on the richness and life forms of the natural regeneration by comparing areas with and without the presence of the introduced grasses.

\section{MATERIALS AND METHODS}

\section{STUDY AREA}

The study was carried out in the National Forest of Carajás in the Amazonian region at Pará State
(Figure 1). The study area lies in a highly preserved area of the mosaic of protected areas of Carajás, being one of the portions least exposed to the effects of intense land use for cattle raising. It represents part of one of the latitudinal widest strips of protected lands in the world. The dominant vegetation of the study area is dense ombrophilous mountainous forest, representing $95 \%$ of the area of the National Forest of Carajás (Secco and Mesquita 1983).

For the exploitation of gold deposits in the "Stream Bahia" in 1980 underground mines and open pits were installed (Figure 2), which resulted in the removal of thousands of tons of soil. The soils were treated chemically for the extraction of ore or stored in open-air cells. In the soils treated chemically for the extraction of gold, the surplus was dumped in tailings basins for settling of sediments. After a few years these basins were abandoned and filled with soil taken from the pits.

In order to rehabilitate the areas altered by the gold mining process and to contain soil erosion,

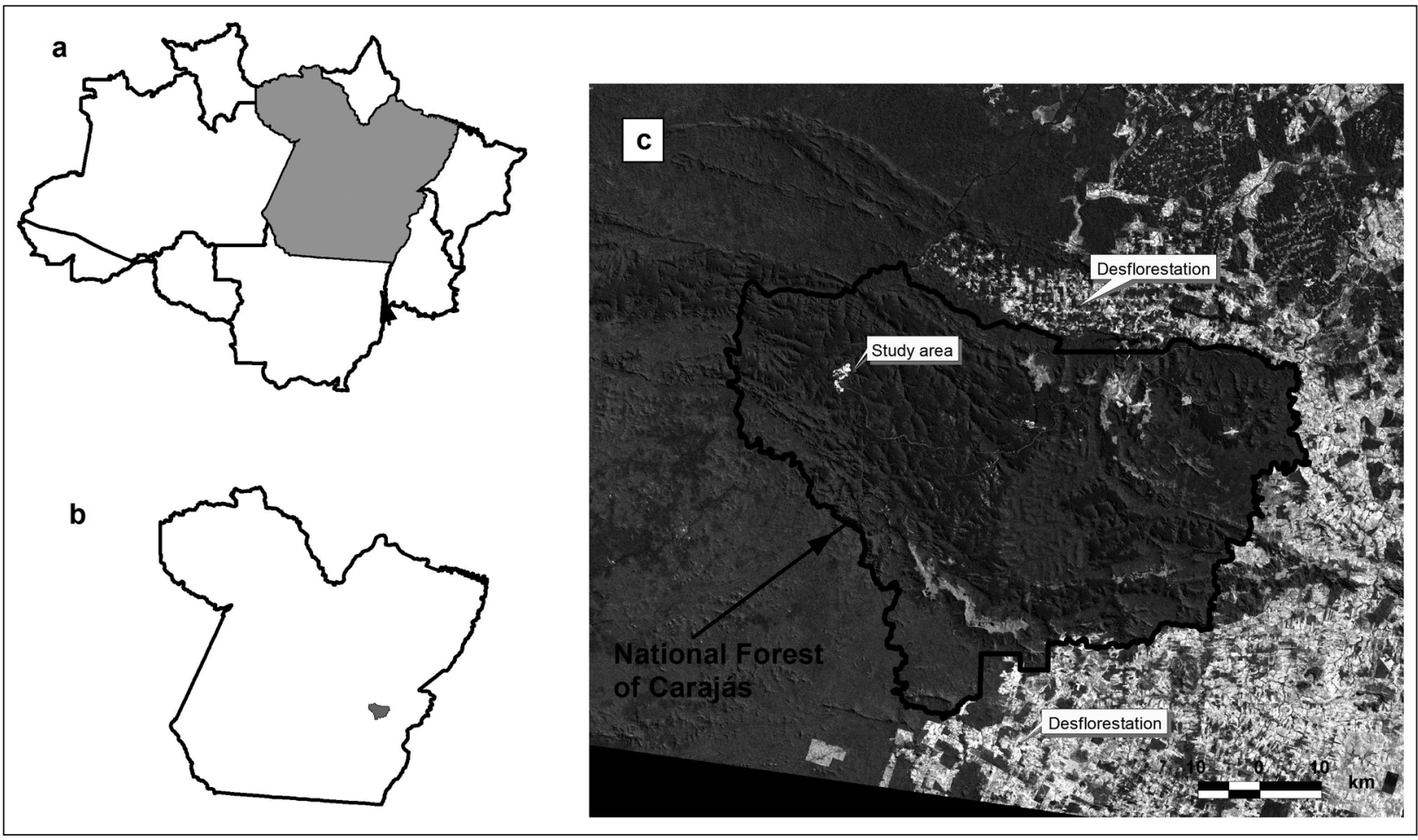

Figure 1 - Map of Amazonian showing the State of Pará, (a) the location of the Carajás National Forest (FLONA of Carajás) in relation to State of Pará (b) and the image of satellite showing location of the study area in the FLONA of Carajás (c). 

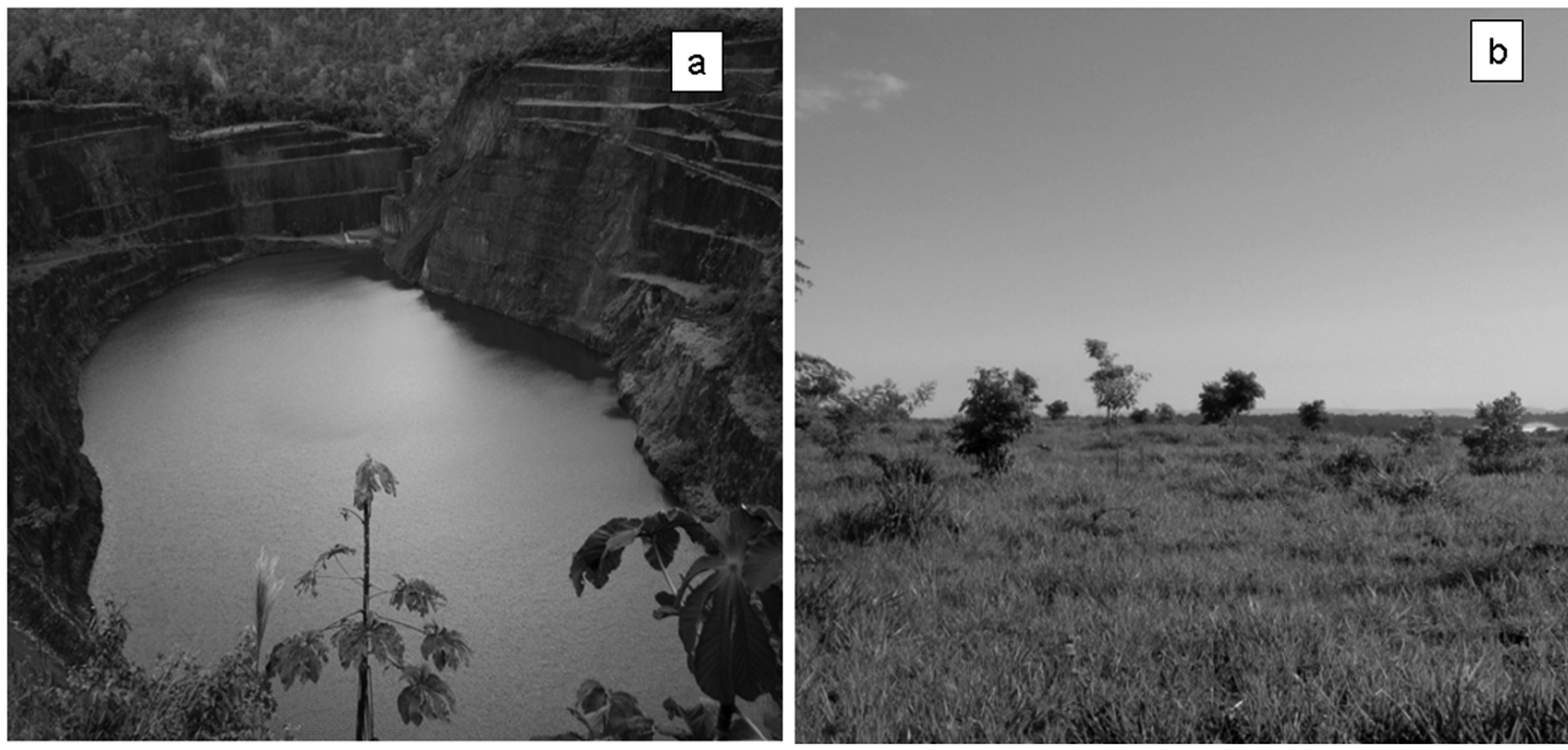

Figure 2 - Open trenches for mineral extraction which resulted in the removal of thousands of tons of soil (a) that were used to the plantation of Urochloa decumbens (Stapf) R.D.Webster (Poaceae) (b).

around the year 1984, the exotic grass U. decumbens was seeded. Subsequently, herbaceous species native from Amazonia were also planted. To date, 20 years after the first rehabilitation processes were initiated, some natural regeneration areas are still dominated by $U$. decumbens.

\section{DATA COLLECTION}

Four plots were selected for this study, two colonized by $U$. decumbens and two colonized by native species from the Amazonian biome, without presence of this exotic grass. In each plot, a linear transect of 500 meters was installed, and every 20 meters a $1 \times 1$ meter plot was marked, totaling 24 plots in each area.

In each plot, all life forms up to $30 \mathrm{~cm}$ height were identified and counted at the genus or species, when possible. Life forms were classified in herbs, ferns, shrubs, trees, lianas and palms. Species were identified by taxonomists of the Paraense Emílio Goeldi Museum. The botanical classification of species was based on the Angiosperm Phylogeny Group (APG III 2008).

\section{DATA ANALYSIS}

Differences of species richness of the natural regeneration in areas with or without $U$. decumbens were tested with Student's t test, and the normality of the data was verified with the Shapiro-Wilk test (Zar 1999).

The species similarity between areas with and without $U$. decumbens was compare by Nonmetric Multidimensional Scaling - NMDS, using the similarity index of Sörensen and the nearest neighbor as link (McCune and Brace 2002).

\section{RESULTS}

The total number of species encountered in this study was 133 . Thirty six species were inventoried in the plots dominated by $U$. decumbens and 103 species where $U$. decumbens was absent (Appendix SI - Supplementary Material).

Species richness in the plots occupied by $U$. decumbens was significantly lower $(X=2.4$; $\mathrm{dp}=1.4$ ) than in the plots where $U$. decumbens was absent $(X=4.8 ; \mathrm{d} p=1.7) .(\mathrm{t}=7,822 ; \mathrm{p}=0.0001)$, clearly demonstrating the negative effect of this grass on species richness (Figure 3 ) 


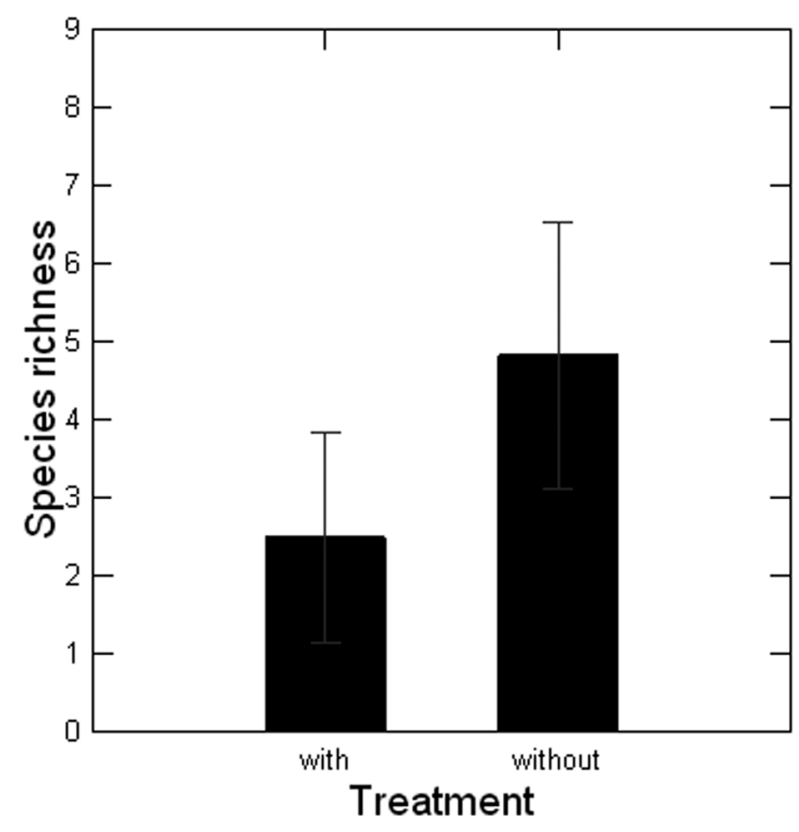

Figure 3 - Mean species richness of natural regeneration with (present) and without (absent) the presence of Urochloa decumbens (Stapf) R.D.Webster (Poaceae).
There was a trend of separation of species composition between the plots with or without presence of $U$. decumbens (Figure 4). Of the 40 tree species present in the study plots, only two tree species ( $5 \%$ of the total) occurred in the plots where $U$. decumbens was present. Similarly, of the 26 species classified as lianas, only one species ( $4 \%$ of total) occurred in the plots dominated by $U$. decumbens. The three species of palms occurred exclusively in the plots without $U$. decumbens (Table I).

Most species classified as herbs with woody tissue and shrubs (46\% of the total) occurred in the plots without $U$. decumbens. They typically belong to undisturbed forests, e.g. Pilocarpus microphyllus Stapf ex Wardleworth (Rutaceae) and Faramea crassifolia Benth. (Rubiaceae). All species typical of secondary vegetation and undisturbed forest were absent from the plots where $U$. decumbens was present (Appendix - SI).

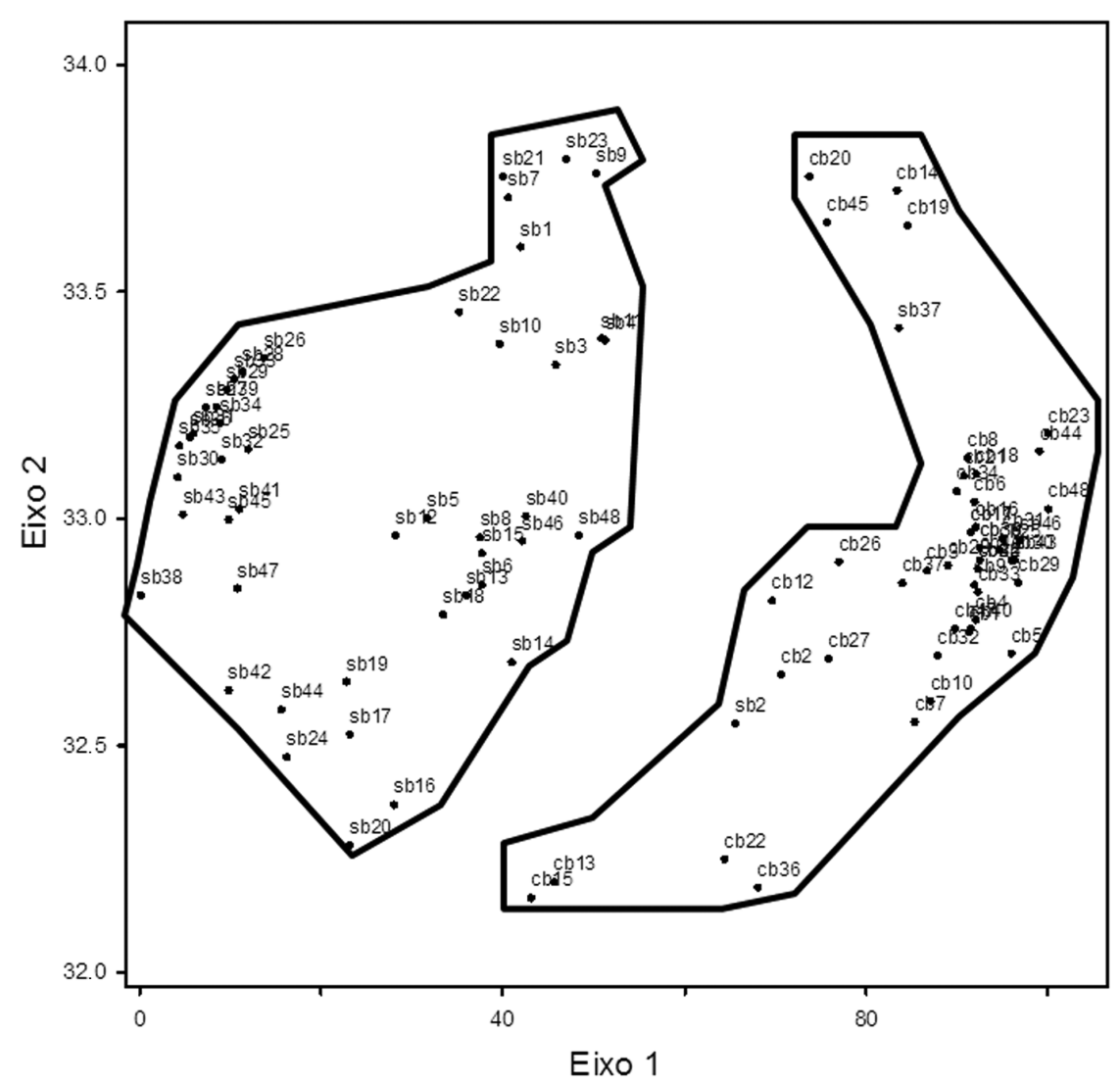

Figure 4 - Species similarity of the natural regeneration plots in areas with (cb) and without ( $\mathrm{sb}$ ) the presence of Urochloa decumbens (Stapf) R.D.Webster (Poaceae). 
TABLE I

Density of individuals and species richness of plant life forms in areas with or without Brachiaria decumbens Stapf (Poaceae).

\begin{tabular}{lcccc}
\cline { 2 - 5 } & \multicolumn{2}{c}{ Density of individuals } & \multicolumn{2}{c}{ Species richness } \\
\hline Life forms & Present & Absent & Present & Absent \\
\hline Scrubs & 7 & 34 & 6 & 8 \\
Trees & 2 & 194 & 2 & 38 \\
Herbs & 406 & 461 & 24 & 28 \\
Ferns & 230 & 5 & 3 & 1 \\
Lianas & 1 & 87 & 1 & 25 \\
Palms & 0 & 5 & 0 & 3 \\
\hline
\end{tabular}

\section{DISCUSSION}

$U$. decumbens is a dominating fast growing $\mathrm{C} 4$ grass with a high demand for light and great competitive ability (Odum and Barrett 2007). As typical for $\mathrm{C} 4$ plants, $U$. decumbens grows well in tropical regions, be it in its native range in South Africa or as invasive species, with high growth rates and investing large amounts of energy in root growth at the expense of other vegetative parts (Ricklefs 2003, Begon et al. 2007). Several species of the genus Urochloa grow up to 1.5 meters high in a few months (Pinheiro 2008), making these species highly aggressive and the co-existence with other species very difficult.

Barbosa et al. (2008) have shown that $U$. decumbens produces phytotoxins which increase its competitive ability, a strategy capable of increasing the success of invasion and inhibiting the establishment and growth of other species in invaded areas. Opportunistic invasive grasses such as $U$. decumbens therefore are characterized by rapid colonization of disturbed or burnt areas (D'Antonio and Vitousek 1992), so that this species may efficiently outcompete and displace native species, causing even local extinctions and loss of biodiversity.

Besides $U$. decumbens, three other alien species were found in the areas of natural regeneration in the studied plots which may influence the composition of species and dominate over native species, although they are less aggressive than $U$. decumbens. These three are Cajanus cajan (Fabaceae), Caesalpinia pulcherrima (Caesalpiniaceae) and Acacia mangium (Fabaceae) (Appendix SI). The first species originates from Asia and is used for farming because of the high nutritional value of its grains and the great capacity of biological fixation of nitrogen (Marin et al. 2004). The second species is originally from Central America and is used as an ornamental plant in urban afforestation. The third species is indigenous to Southeast New Guinea and Australia and widely used in reforestation industrial plantations for wood and charcoal production (Dias et al. 1991) and it is considered of great potential for the recovery of areas degraded by mining (Yared et al. 1988).

In fact, their presence in our study plots with natural regeneration is due to plantings after the establishment of $U$. decumbens in order to facilitate the reforestation of the area. However, their presence is not desired nowadays as they are exotic invasive species and may have negative effects on the establishment of the local flora.

The dominant coverage of the study plots by $U$. decumbens is evident and it is presumed to be the factor which mostly influences the presence of other plant species. As typical exotic invasive grass species, $U$. decumbens produces a dense layer in the soils reducing drastically the light incidence on the surface, which may avoid the germination processes and recruitment of native species from seed banks or dispersed seeds. 
Invasive species like $U$. decumbens also can alter ecological processes such as nutrient cycles. It dramatically reduces the amount of inorganic nitrogen in the soil due to its high uptake capacity, and uses this element for its growth depleting the soils (Pivello et al. 1999). As a result, other ecological processes, such as the dynamics of species succession in natural regeneration in areas with $U$. decumbens can be altered.

However, other factors might explain the lower species richness in the plots where $U$. decumbens is present, such as weeding and cleaning of the area that frequently occurs in the study area. Also, the quality of the soil from the mining excavation inhibits plant growth of non-tolerant species. The acidity of the soil remnants of mining inhibits the establishment of vegetation in the recovery process and also affects the availability of nutrients and the biological processes of plants (Berg 1965). The dominance of $U$. decumbens is certainly linked to its high tolerance of these conditions, and both poor soil conditions and the dense growth of the invasive grass inhibit the presence of a diverse flora.

Cheung et al. (2009) showed that in abandoned pasture areas in Paraná, Brazil, previously covered by dense ombrophilous forest, the establishment and development of woody vegetation was inversely related to the presence of $U$. decumbens and that this negatively affects grass in the natural regeneration of the forest even without the presence of toxic compounds in the soils. Filippo et al. (2007) showed that in disturbed cerrado areas in the National Park Serra do Cipó in Minas Gerais, Brazil, which were later colonized and dominated by $U$. decumbens, a lower richness and diversity of herbaceous species was evident. They suggest that places dominated by fast growing grasses should be prioritized in the restoration as they are easily dispersed and invade vast areas.

Therefore, the control or eradication of invasive species such as $U$. decumbens is highly recommended. This can be done by mechanical, chemical, or biological techniques, which inhibit the invasive species and/or encourage native species (Wittenberg and Cock 2001). However, all techniques known today have their pros and cons, and opinions differ as to their effectiveness. Field and laboratory experiments that analyze the efficiency of the different methods and their environmental impact are necessary. The introduction of potentially invasive species must be restricted a priori, so that invasive species such as $U$. decumbens cannot dominate the environment and cause damage to the original species distribution and ecosystems' functioning, even causing local extinctions of species.

Pivello (2009) states that it is essential that policies should be implemented for the control of exotic species, and in the case of protected areas it is recommended to make the planning of land use in the surrounding areas, establishing buffer zones that are mainly occupied by evergreen tree species, to keep a distance from planted pastures in order to avoid that invasive grasses spread into protected units.

We suggest implementing a project of recovery of the mining areas invaded by $U$. decumbens and plant native species of primary and secondary forest. The growth of these species will provide shaded areas where the invasive $U$. decumbens does not have much capacity for growth.

This study showed the negative effect of $U$. decumbens on species richness, composition and distribution of life forms of the natural regeneration in a lowland Amazonian forest area. It is highly recommended to put efforts to set up research projects which analyze alternative techniques for the restoration of degraded areas and for the recuperation of areas invaded by invasive species in the Carajás National Forest.

\section{ACKNOWLEDGMENTS}

The authors thank the students of the field course of ecology of the program of post-graduation in 
zoology of the Museu Paraense Emílio Goeldi and the Universidade Federal do Pará for help in collection the data. The Companhia Vale and the Instituto Chico Mendes para a Conservação da Biodiversidade for help with logistics for the course.

\section{RESUMO}

A introdução de espécies exóticas é considerada uma das principais causas da perda de biodiversidade. A Floresta Nacional de Carajás é uma das maiores províncias minerais do mundo. As atividades da mineração provocaram alterações dos habitats naturais, deixando áreas degradadas após a exploração mineral. Uma das áreas de mineração dentro da FLONA de Carajás foi usada para a extração de ouro. No processo de exploração, uma enorme cava foi formada pela remoção do solo que foi colocado em montes nas proximidades. Para evitar a erosão do solo desses montes, uma gramínea exótica, Urochloa decumbens (Stapf) R.D.Webster (Poaceae) foi plantada. O objetivo deste estudo foi comparar o impacto desta gramínea não-nativa na riqueza de espécies e composição de espécies da regeneração natural nas áreas degradadas. Quatro áreas foram comparadas, duas com e duas sem a presença de $U$. decumbens. Em cada área, vinte e quatro parcelas de $1 \mathrm{~m}^{2}$ foram estabelecidas. A riqueza de espécies e os tamanhos das populações da regeneração natural foram significativamente menores nas parcelas onde a gramínea exótica estava presente. Nosso estudo mostra que $U$. decumbens tem um efeito negativo sobre a riqueza de espécies e densidade populacional e sua presença alterou a composição e distribuição de formas de vida da regeneração natural das espécies.

Palavras-chave: espécies exóticas, áreas degradadas, florística, mineração.

\section{REFERENCES}

Alho CJR, Mamede S, Bitencourt K AND Benites M. 2011. Introduced species in the Pantanal: Implications for conservation. Braz J Biol 71(1): 321-325.

APG III. 2008. An update of the Angiosperm Phylogeny Group classification for the orders and families of flowering plants: APG III. Bot J Linn Soc 161: 105-121.
BArbosa EG, PIVEllo VR AND MeIRElles ST. 2008. Allelopathic evidence in Brachiaria decumbens and its potential to invade the Brazilian Cerrados. Braz Arch Biol Technol 51(4): 625-631.

BEGON M, TOWNSEND CR AND HARPER JL. 2007. Ecologia: de indivíduos a ecossistemas. $4^{\mathrm{a}}$ ed., Porto Alegre: Artmed Editora, 752 p.

BERG WA. 1965. Plant-toxic chemicals in acid spoils. In: Proceedings of the coal mine spoil reclamation symposium. The Pennsylvania State University, University Park, p. 91-93.

BIANCO S, BRENDOLAN RA, ALVES PLCA AND PITELLI RA. 2000. Leaf area estimative in weeds Urochloa decumbens (Stapf) R.D.Websterand Brachiaria brizantha (Hochst.) Stapf. Planta Daninha 18(1): 79-83.

CARPANEZZI AA, COSTA LGS, KAGEYAMA PY AND CASTRO CFA. 1990. Espécies pioneiras para recuperação de áreas degradadas: observação de laboratórios naturais. In: Anais do Congresso Florestal Brasileiro, 6, Campos do Jordão. São Paulo. Sociedade Brasileira de Silvicultura, p. 216221.

Cheung KC, MARques MCM AND LiebsCH D. 2009. Relationship between herbaceous vegetation and regeneration of woody species in abandoned pastures in the Atlantic Rain Forest in Southern Brazil. Acta Bot Bras 23(4): 1048-1056.

CORRÊA RS AND LEITE LL. 1998. Ecologia e regeneração em áreas escavadas. In: Corrêa RS and Mello FB (Eds), Ecologia e recuperação de áreas degradadas no cerrado. Brasília, p. 29-48.

D’Antonio CM And VitouseK PM. 1992. Biological invasions by exotic grasses, the grass/fire cycle, and global change. Ann Rev Ecol Syst 23: 63-87.

DIAS LE, ALVARES VH AND BRIENZA S. 1991. Formations of seedlings of Acacia mangium Wild: Responses to nitrogen and potassium. Rev Árvore 15(1): 1-19.

FILIPPO DC, RIBEIRO LC, NASCIMENTO JS, MADEIRA JA AND RIBEIRO KT. 2007. "Projeto Cipó Vivo, Combatendo a Braquiária" - Análise de diversidade em áreas dominadas por capim braquiária (Brachiaria decumbens Stapf) e grama batatais (Paspalum notatum A. H. Liogier ex Flüggé), em duas unidades de conservação contíguas em Minas Gerais. Anais do VIII Congresso de Ecologia do Brasil, Caxambu, Minas Gerais, p.1-2.

KAGEYAMA P AND GANDARA FB. 2004. Recuperação e conservação de ecossistemas tropicais. In: Cullen JR et al. (Eds), Métodos de estudo em Biologia da Conservação \& Manejo da vida silvestre. Curitiba: Fundação O Boticário de Proteção à natureza, UFPR, p. 383-394.

KOLAR CS AND LODGE DM. 2001. Progress in invasion biology: predicting invaders. Tree 16: 199-205.

MARIN A, SANTOS DMM, ARIOVALDO D AND FERRAUDO AS. 2004. Seed germination of pigonpea (Cajanus Cajan (L.) Millsp.) under water stress and aluminum sublethal doses. Bragantia 63(1): 13-24. 
MATOS DMS AND PIVELLO VR. 2009. O impacto das plantas invasoras nos recursos naturais de ambientes terrestres: alguns casos brasileiros. Cien Cult 61: 27-30.

MCCUNE B AND BRACE JB. 2002. Analysis of ecological communities. MjM Software Design, Gleneden Beach. Oregon.

OdUM EP AND BARRETT GW. 2007. Fundamentos de Ecologia. $5^{\text {a }}$ ed., São Paulo: Thomson Learning, 612 p.

PINHEIRO CQ. 2008. Avaliação da recuperação da cascalheira do aeroporto internacional de Brasília - Juscelino Kubitschek: aspectos edáficos, florísticos e ecológicos. Dissertação de Mestrado. Universidade Federal de Brasília, Brasília, 84 p.

PIVELlo VR. 2009. Invasões Biológicas no Cerrado Brasileiro: Efeitos da Introdução de Espécies Exóticas sobre a Biodiversidade. Ecologia. INFO 33. Disponível em: $<$ http://www.ecologia.info/cerrado.htm.>. Accessed 20 June 2012.

PIVEllo VR, ShIDA CN AND MeIRElles ST. 1999. Alien grasses in Brazilian savannas: a three eat to biodiversity. Biodivers Conserv 8: 1281-1294.

RAY GJ AND BROWN BJ. 1995. Restoring Caribbean dry forests: evaluation of tree propagation techniques. Restor Ecol 3: 86-94.

RICKLEFS RE. 2003. A Economia da Natureza. 5a ed., Rio de Janeiro: Guanabara Koogan, 542 p.

SALOMÃO RP, ROSA NA AND MORAIS KAC. 2007. Dynamics of natural tree regeneration after strip-mining in the Amazon. Bol Mus Para Em Goeldi Cien Nat 2(2): 85-139.

SECCO R AND MESQUITA AL. 1983. Notas sobre a vegetação de canga da Serra Norte. Bol Mus Para Em Goeldi Bot 59: $1-13$
SESTREN-BASTOS MC. 2007. Planejamento estratégico da remoção de espécies exóticas invasoras no Parque Natural Morro do Osso. Trabalho de Conclusão de Curso (PósGraduação em MBA Gestão Pública) - Faculdade IBGEN, Porto Alegre, $56 \mathrm{p}$.

STRAYER DL. 2012. Eight questions about invasions and ecosystem functioning. Ecol Lett 15: 1199-1210.

TILstone GH, PASIECZNIK NM, HARIZ PJC AND WAINWRIGHT SJ. 1998. The growth of multipurpose tree species in the Almeria province of Spain and its relationship to native plant communities. Int Tree Crop J 9: 247-259.

WITTENBERG R AND COCK MJW. 2001. Invasive Alien Species: A toolkit of best prevention and management practices. Wallingford: CAB International, Oxon, UK, 228 p.

YARED JAG, KANASHIRO M AND CONCEIÇÃO JGL. 1988. Espécies florestais nativas e exóticas: comportamento silvicultural no plantio do Tapajós. Embrapa-CPATU, 29 p.

ZAR JH. 1999. Biostatistical Analysis. New Jersey: PrenticeHall, $544 \mathrm{p}$.

ZILLER SR. 2001. Plantas exóticas invasoras: a ameaça da contaminação biológica. Cienc Hoje 30(178): 77-79.

\section{SUPPLEMENTARY MATERIAL}

Appendix SI - List of species and life forms identified in this study. Two transects with presence of Urochloa decumbens (Stapf) R.D.Webster (Poaceae) (Present1 and 2) and two with absence (Absent 1 and 2). * Exotic species. 